\title{
Service Area Coverage with Economic Infrastructure and Accessibility by the Local Society
}

Sudmitted 24/2/18 $1^{\text {st }}$ revision 26/6/18, $2^{\text {nd }}$ revision $12 / 9 / 18,3^{\text {rd }}$ revision $11 / 1 / 19$, accepted 10/3/19

\author{
Irwan Wunarlan ${ }^{1}$
}

\begin{abstract}
:
Purpose: One region in Gorontalo Province that has a high economic growth rate is Pohuwato District with Marisa as the capital. Marisa City, as the core area and as the center of new growth, needs economic infrastructure services to support the economic activity so it can promote the economic growth of the city and the region as well.

Design/Methodology/Approach: It requires studies on the service coverage of economic infrastructure and accessibility from the activities center for the development of a region. This research used the descriptive quantitative method. Data were collected through surveys from various institutions while secondary data were originating from BPS (Statistics Indonesia) Pohuwato District in 2016. The research consists of three stages of analysis, namely: (1) accessibility analysis, (2) scalogram analysis and (3) economic service coverage analysis.

Findings: The results show that accessibility in Randangan Sub-district has a better service coverage in terms of equitable accessibility compared to Marisa City and Paguat Subdistrict. However, the calculation of the gravity model on Marisa City (urban) has a high attraction towards other sub-districts (hinterland).

Practical implications: Marisa City has a higher accessibility than its hinterland areas, that is Duhiadaa (67.16), Buntulia (17.93) and Paguat $(11,88)$ sub-districts. In addition, Marisa City (Marisa Sub-district) has the highest function index value that places Marisa Subdistrict in the first order followed by the Paguat, Randangan and Patilanggio Sub-district.

Originality/Value: No other study has approached the issue from this prospective making the present study unique for the development of infrastructure in services.
\end{abstract}

Keywords: Infrastructure, economic service, region, urban, hinterland region.

Paper type: Research article.

\footnotetext{
${ }^{1}$ Postgraduate Stundent of Diponegoro University, e-mail: wunarlan.irwan@gmail.com
} 


\section{Introduction}

Regional development is an event examining the behavior of different regions and the interaction of human resources with other resources over space. Regional development, in developing as well as developed countries, is generally predicated on two things, which are: (1) the desire to achieve a set of national objectives and (2) to reduce the inequality of economic growth between regions. However, it is generally known that the potential and capabilities of each region varies. There are three fundamental elements in regional development, mainly: (1) service/growth centers; (2) influences or services in each center; (3) transportation network. Moreover, the regional development has inter-connections (connectedness) and dependence between spaces (Adisasmita, 2014b).

Potential, characteristics, and conditions between regions vary as well. A region can be viewed from various aspects, such as geographic, topographic, demographic, infrastructure, economic, social, cultural, and ethnological aspects (McCann, 2004). A region can also be viewed through regional and spatial dimension; these dimensions are the new variables in the economic analysis used for regional development (Adisasmita, 2014a).

The differences that exist between regions can be approached with the nodal region concept. A nodal region is essentially based on inequality or heterogeneity factors; however, this distinction is the basis to a harmonious and functional interrelationship (Williams, 2014). The structure of nodal regions can be illustrated as a living and growing cell constituted from two regional components, that is, the main area (core, central, metropolis) and the periphery area (rural, suburban, hinterland) as the part of the surrounding which is complementary to its focal area. In addition, the nodal region consists of parts with distinct functions. On such structure, functional integration will be created as the basis of relations between communities in the nodal region (Wibowo \& Soetriono, 2004).

The rate of economic growth becomes one factor of the growth process within a region. Economic growth is always assisted with an increase in local revenue, where infrastructure and utilities participate in driving the economic activity in local, regional or national scale altogether. The provision of infrastructure and utilities services influences both the macro and the micro-economy. The influence of infrastructure services in macro-economy may affect the marginal productivity of private capital; while in micro-economy, it can lower the production costs. Improving the quality of life and welfare can be done through increasing the consumption rate, increasing the productivity of labor and accessibility to employment, as well as, increasing actual prosperity and the realization of macroeconomic stability. It involves fiscal sustainability, the development of credit markets and its effects on the labor market which is affected by the provision of infrastructure and utilities services (Haris, 2009). 
Normatively, infrastructure should be able to resolve the economic problems in a region, for example, poverty. It should not only pursue the economic growth, but also run harmoniously. When the infrastructure development proceeds, it will improve the quality of life of the community and increase the employment; so that it eventually affects the improvement of community welfare. Empirical facts reveal that infrastructure development in a region will affect the economic output. Furthermore, even the World Bank (1994) states that an increase of $1 \%$ of the infrastructure alone could create an increase in GDP of 1\% (Al Karim, 2012).

Pohuwato District is a region in Gorontalo Province with a high economic growth rate. The economic growth rate in this region reaches 7.46 percent per year with a population growth of 3.26 percent (Badan Pusat Statistik, Central Bureau of Statistics, 2016). Marisa is the capital city of Pohuwato District. Marisa City is the center (core) of Pohuwato District. Marisa City is located $\pm 158 \mathrm{~km}$ from the National Activity Centre (PKN) of Gorontalo. Since 2003, this city has grown and thrived to be one of the new growth centers in the Western Gorontalo Province (Tuloli, 2013). The development of the Marisa city is supported by the availability of infrastructure and utilities of the city, as well as, good transport accessibility which makes Marisa City the center of various activities such as government services, education, health, economics, and culture. The provision of various infrastructure and utilities of the city is intended to deliver great service for the citizens. The availability and completeness of infrastructure and utilities of this city became an attraction for the investors, the citizen and its surroundings. Marisa, as the core area and as the center of new growth, requires economic service infrastructures to support the economic activity so it can promote an increase in the economic growth of the city and the region as well. Therefore, studies on the economic infrastructure of the service area coverage of economic infrastructure and accessibility from the activity center in regional development are called for.

\section{Research Methods}

\section{A. Location and Time of the Research:}

This research was carried out in Pohuwato District, Gorontalo Province between January and August 2017. This research used a descriptive quantitative method.

\section{B. Data Collection Technique:}

Data were collected through surveys conducted in the institutions and the data collected is secondary data originating from BPS (Statistics Indonesia) Pohuwato District. Secondary data collected will serve as the basis for measuring the level of accessibility and infrastructure service. The economic infrastructure in this study refers to Adisasmita (2010). Economic infrastructure includes shops and kiosks, restaurants (cafe and diner), banks, hotels, industries, markets, village unit cooperatives, terminals, informal services (beauty salon, barbershop, and screen printing/printing) and non-bank financial services. Travel distance $(\mathrm{km})$ is used to 
measure the accessibility between the hinterland region (rural) and Marisa City (core).

\section{Method of Analysis:}

The methods used in this study consists of three (3) stages of analysis, that is:

1. Economic Service Coverage Analysis:

The result of scalogram analysis is then further proceeds with the calculation of coefficient reproducibility to identify the validity of the analysis. The equation of coefficient reproducibility is as follows:

$\mathrm{CR}=1-\frac{\sum \theta}{n x k}$

where:

$\mathrm{CR}=$ coefficient reproducibility;

$\sum \mathrm{e}=$ total errors;

$\mathrm{n} \quad=$ number of sub-districts;

$\mathrm{k} \quad=$ number of variables.

According to Abdi (2005), Guttman said that the CR limit tolerated is 0.90. If the value is lesser, then the results are not approaching the actual scale.

\section{Scalogram Analysis:}

The Scalogram model is one of the easiest regional planning methods. Using this model, we can create a matrix to specify which settlements are in better conditions. The model has applications both for human aspects and for natural regional plans. The model is a mathematical and statistical method in ranking the members of a cluster with respect to the index of development based on necessity and priority decided upon (Pour \& Firozjaei, 2012). On the other hand, this analysis can be used to find out the function and hierarchy of development centres as well as developing infrastructure in an area (Marasabessy, 2016). This method is a simple one since it only displays the list of components of the supporters. The required components usually include: (1) reviewed residential/regional data, (2) population of the corresponding residential area, and (3) function/facility data of services at each residential area (Abdi, 2005; Riyadi \& Bratakusumah, 2004).

\section{Accessibility Analysis:}

Accessibility analysis is used to find out the level of accessibility from the rural area (hinterland) to the growth center, so that data about the number of infrastructures is required. The availability of the number and nature of the infrastructures in an area is the attraction of that region. Accessibility between regions can be measured by using a gravity model. Hence, each location is assumed as a mass with attractive characteristics. Spatial distance is used to approach spatial interaction between city centers or the two masses; the distance between the two masses highly determines 
the magnitude of the attraction arising from those two masses. The closer the distance between two locations, the greater the attraction between them. On the contrary, the greater the distance between two locations, the smaller or weaker the attraction between them or it can lower the consumers' or residents' utility (Mani Kannan, 2015; Setiono, 2011; Lal \& Pathak, 2011; Bintarto, 1983). Therefore, the attraction between the two locations is inversely proportional to their distance. Next, referring to Newton's law of gravitation, then magnitude of attraction or interaction between the two locations is proportional to the masses multiplication (population) and inversely proportional to the distance squared, or in the form of a formula as expressed in the following:

$\mathrm{F}_{12}=K \frac{\left(P_{1}\right) x\left(P_{2}\right)}{\left(d_{12}^{2}\right)}$

where:

$\mathrm{F}_{12}=$ attraction between location 1 and location 2;

$\mathrm{P}_{1} \quad=$ the size of population at location 1 ;

$\mathrm{P}_{2} \quad=$ the size of population at location 2;

$\mathrm{K}_{\mathrm{i}} \quad=$ constant (availability of economic infrastructure in an area derived from scalogram analysis);

$\mathrm{d}_{12}=$ distance between location 1 and location 2 .

In the spatial interaction or gravity model there are two basic elements, namely: (1) scale impact: for example, a city with a massive population is likely to produce and attract more activities than a city with a smaller population, and (2) distance impact: for example, the farther the places, people or activities, the lesser the interactions (Kingsley \& Fotheringham, 1984).

\section{Results and discussion}

\section{Scalogram Analysis:}

Based on the scalogram analysis, an overview of the economic service infrastructure distribution in Puhowato District is obtained. Marisa Sub-district has the highest Function Index value, placing it in the first order, followed by Paguat, Randangan and Patilanggio sub-district consecutively. It indicates that Marisa Sub-district is the center of economic infrastructure service. Furthermore, Marisa City is the capital of the Pohuwato District, so that the available infrastructure in this area is complete and can meet the needs of its citizens. The calculation results of the scalogram analysis on the economic infrastructure service are presented in Table 1.

Table 1. Results of Scalogram on the Infrastructure of Pohuwato District

\begin{tabular}{|c|c|c|c|c|c|c|c|c|c|c|c|c|c|c|c|}
\hline \multirow[t]{2}{*}{ No } & \multirow{2}{*}{$\begin{array}{l}\text { Sub- } \\
\text { district }\end{array}$} & \multirow{2}{*}{$\begin{array}{l}\text { Populatio } \\
\mathrm{n}\end{array}$} & Typ & of Ec & omi & frast & ture & & & & $\begin{array}{l}\text { Tota } \\
1\end{array}$ & \multicolumn{2}{|l|}{ Index } & \multirow[b]{2}{*}{$\begin{array}{l}\text { Typ } \\
\mathrm{e}^{\text {Typ }}\end{array}$} & \multirow{2}{*}{$\begin{array}{l}\text { Rank } \\
\begin{array}{l}\text { Functio } \\
\mathrm{n}\end{array}\end{array}$} \\
\hline & & & $\mathrm{A}$ & $\mathrm{B}$ & $\mathrm{C}$ & $\mathrm{D}$ & $\mathrm{E}$ & $\mathrm{F}$ & $\mathrm{G}$ & $\mathrm{H}$ & & $\mathrm{J}$ & Unit & & \\
\hline 1 & Marisa & 20112 & 909 & 30 & 9 & 13 & 390 & 1 & 23 & 349 & 12 & 1 & $\begin{array}{l}173 \\
7\end{array}$ & 10 & 173.70 \\
\hline
\end{tabular}




\begin{tabular}{|c|c|c|c|c|c|c|c|c|c|c|c|c|c|c|c|c|}
\hline 2 & $\begin{array}{l}\text { Randanga } \\
\mathrm{n}\end{array}$ & 16512 & 345 & 11 & 2 & 1 & 94 & 1 & 11 & 112 & 11 & 0 & 588 & 9 & 65.33 & 3 \\
\hline 3 & Paguat & 15748 & 338 & 9 & 2 & 2 & 202 & 2 & 15 & 167 & 6 & 0 & 743 & 9 & 82.56 & 2 \\
\hline 4 & Duhiadaa & 11518 & 208 & 10 & 3 & 3 & 138 & 1 & 12 & 60 & 8 & 0 & 443 & 9 & 49.22 & $\begin{array}{l}5 \\
1\end{array}$ \\
\hline 5 & Buntulia & 10986 & 70 & 2 & 0 & 2 & 120 & 0 & 6 & 39 & 4 & 0 & 243 & 7 & 34.71 & 0 \\
\hline 6 & Lemito & 10972 & 171 & 9 & 1 & 1 & 65 & 1 & 12 & 93 & 4 & 0 & 357 & 9 & 39.67 & 9 \\
\hline 7 & $\begin{array}{l}\text { Popayato } \\
\text { Patilanggi }\end{array}$ & 9565 & 216 & 4 & 0 & 4 & 62 & 1 & 7 & 49 & 8 & 1 & 352 & 8 & 44.00 & 7 \\
\hline 8 & o & 9517 & 189 & 1 & 0 & $\mathbf{0}$ & 108 & 2 & 5 & 93 & 1 & $\mathbf{0}$ & 399 & 7 & 57.00 & $\begin{array}{l}4 \\
1\end{array}$ \\
\hline 9 & $\begin{array}{l}\text { Taluditi } \\
\text { East }\end{array}$ & 7829 & 138 & 1 & 0 & 0 & 68 & 2 & 7 & 19 & 1 & 0 & 236 & 7 & 33.71 & 1 \\
\hline 10 & $\begin{array}{l}\text { Popayato } \\
\text { West }\end{array}$ & 7798 & 104 & 5 & 1 & $\mathbf{0}$ & 155 & 2 & 6 & 64 & 5 & 0 & 342 & 8 & 42.75 & 8 \\
\hline 11 & Popayato & 6835 & 119 & 3 & 0 & 0 & 129 & 2 & 6 & 60 & 2 & 0 & 321 & 7 & 45.86 & $\begin{array}{l}6 \\
1\end{array}$ \\
\hline 12 & $\begin{array}{l}\text { Dengilo } \\
\text { Wanggara }\end{array}$ & 5691 & 53 & 28 & $\mathbf{0}$ & 0 & 84 & 1 & 5 & 41 & 2 & 0 & 214 & 7 & 30.57 & $\begin{array}{l}2 \\
1\end{array}$ \\
\hline 13 & si & 4748 & 79 & 5 & $\mathbf{0}$ & 0 & 13 & 1 & 6 & 33 & 0 & 0 & 137 & 6 & 22.83 & 3 \\
\hline & $\sum$ Unit & 137831 & $\begin{array}{l}293 \\
9 \\
\end{array}$ & $\begin{array}{l}11 \\
8 \\
\end{array}$ & 18 & 26 & $\begin{array}{l}162 \\
8 \\
\end{array}$ & 17 & $\begin{array}{l}12 \\
1 \\
\end{array}$ & $\begin{array}{l}117 \\
9 \\
\end{array}$ & 64 & 2 & $\begin{array}{l}611 \\
2 \\
\end{array}$ & & & \\
\hline & $\sum$ Type & & 13 & 13 & 6 & 6 & 13 & 12 & 13 & 13 & 12 & 2 & & & & \\
\hline & $\begin{array}{l}\text { Weight } \\
\text { Value }\end{array}$ & & 7.7 & 7.7 & $\begin{array}{l}16 . \\
7\end{array}$ & $\begin{array}{l}16 . \\
7 \\
\end{array}$ & 7.7 & $\begin{array}{l}8 . \\
3 \\
\end{array}$ & 7.7 & 7.7 & 8.3 & $\begin{array}{l}50 . \\
0 \\
\end{array}$ & & & & \\
\hline
\end{tabular}

Source: Result of the Research, 2017

Description:

$\begin{array}{llllr}\text { A } & \text { Shop/Kiosk/Stall } & \mathrm{D}=\text { Hotel } & \mathrm{G}=\text { Village Unit Cooperation } & \mathrm{J}=\mathrm{Terminal} \\ \mathrm{B} & \text { Restaurant/Cafe/Diner } & \mathrm{E}=\text { Industry } & \mathrm{H}=\text { Informal Service } \\ = & \mathrm{F}=\text { Market } & \mathrm{I}=\text { Non-Bank Financial Service }\end{array}$

\section{Analysis of Economic Infrastructure Services:}

The validity of the scalogram analysis obtained a value of 0.907 from the calculation performed using equation (2). It indicates that the results of the scalogram analysis are approaching the actual scale.

$\mathrm{CR}=1-\left(\frac{12}{13 \times 10}\right)=0,908$

Scalogram analysis generates service capabilities in each sub-district in Pohuwato District. Marisa City is a sub-district with a good service, since it placed first in the order of urban hierarchy system in Pohuwato District, consecutively followed by Paguat, Randangan and Patilanggio Sub-district.

\section{Accessibility Analysis:}

Population, distance, and availability of various economic infrastructure services are utilized as the variables to analyze the attraction of an urban area towards the rural area (hinterland). For example, the calculation of attraction between Marisa City (urban) and Randangan Subdistrict (hinterland) are presented below: 
$\mathrm{F}_{\text {Randangan-Marisa }}=K_{i} \frac{P_{\text {Randangan }} P_{\text {Marisa }}}{d_{\text {Randangan Marisa }}^{2}}$

$\mathrm{F}_{\text {Randangan-Marisa }}=\frac{588}{6112} X \frac{16512 \times 20112}{\left(11^{2}\right)}=26080.3=2.61$

The calculation for Randangan Sub-district turned out that its accessibility has a better service coverage in terms of equitable accessibility when compared to Marisa City and Paguat Sub-district. However, the calculation of the gravity model on Marisa City (urban) results in a high attraction towards other sub-districts (hinterland). Marisa City has a high accessibility value to its hinterland Duhiadaa (67.16), Buntulia (17.93) and Paguat $(11,88)$ Sub-district. The results of the calculation of gravity model are presented in Table 2.

Table 2. Results of the Research of Gravity Model Based on Infrastucture in Pohuwato District

\begin{tabular}{|c|c|c|c|c|c|c|c|c|c|c|c|}
\hline $\begin{array}{l}\mathrm{N} \\
\mathrm{o} .\end{array}$ & $\begin{array}{l}\text { Sub- } \\
\text { district }\end{array}$ & $\begin{array}{l}\text { Populat } \\
\text { ion }\end{array}$ & $\begin{array}{l}\begin{array}{l}\text { Dista } \\
\text { nce }\end{array} \\
(\mathrm{km})\end{array}$ & $\begin{array}{l}\text { Gravit } \\
\text { y } \\
\text { Maris } \\
\text { a }\end{array}$ & $\%$ & $\begin{array}{l}\begin{array}{l}\text { Dista } \\
\text { nce }\end{array} \\
(\mathrm{km})\end{array}$ & $\begin{array}{l}\text { Gravit } \\
\mathrm{y} \\
\text { Pagua } \\
\mathrm{t}\end{array}$ & $\%$ & $\begin{array}{l}\begin{array}{l}\text { Dista } \\
\text { nce }\end{array} \\
(\mathrm{km})\end{array}$ & $\begin{array}{l}\text { Gravity } \\
\text { Randan } \\
\text { gan }\end{array}$ & $\%$ \\
\hline & & & & & 0.0 & & 27781 & 69. & & 77043 & 47. \\
\hline \multirow[t]{2}{*}{1} & Marisa & 20112 & 0 & 0.0 & 0 & 18 & 2.7 & 16 & 35 & 4 & 37 \\
\hline & Randan & & & 26080 & 2.3 & & 8905. & 2.2 & & & 0.0 \\
\hline \multirow[t]{2}{*}{2} & gan & 16512 & 35 & .3 & 8 & 53 & 7 & 2 & 0 & 0.0 & 0 \\
\hline & & & & 11883 & 10. & & & 0.0 & & 11253. & 6.9 \\
\hline \multirow[t]{2}{*}{3} & Paguat & 15748 & 18 & 4.1 & 83 & 0 & 0.0 & 0 & 53 & 3 & 2 \\
\hline & Duhiada & & & 67160 & 61. & & 24852 & 6.1 & & 15316. & 9.4 \\
\hline \multirow[t]{2}{*}{4} & $\mathrm{a}$ & 11518 & 5 & 3.1 & 21 & 23 & .3 & 9 & 30 & 3 & 2 \\
\hline & Buntuli & & & 17927 & 16. & & 11005 & 2.7 & & & 5.6 \\
\hline \multirow[t]{2}{*}{5} & $\mathrm{a}$ & 10986 & 7 & 5.8 & 34 & 25 & .5 & 4 & 28 & 9199.1 & 6 \\
\hline & & & & 2707. & 0.2 & & 1333. & 0.3 & & & 5.6 \\
\hline \multirow[t]{2}{*}{6} & Lemito & 10972 & 69 & 2 & 5 & 87 & 4 & 3 & 34 & 9154.0 & 3 \\
\hline & Popayat & & & 1367. & 0.1 & & & 0.1 & & & 1.8 \\
\hline \multirow[t]{2}{*}{7} & o & 9565 & 90 & 8 & 2 & 108 & 743.7 & 9 & 55 & 3006.9 & 5 \\
\hline & Patilang & & & 86772 & 7.9 & & 10871 & 2.7 & & 21195. & 13. \\
\hline \multirow[t]{2}{*}{8} & gio & 9517 & 12 & .6 & 1 & 30 & .1 & 1 & 22 & 5 & 03 \\
\hline & & & & 1581. & 0.1 & & & 0.1 & & & 4.2 \\
\hline \multirow[t]{3}{*}{9} & Taluditi & 7829 & 62 & 6 & 4 & 80 & 743.8 & 9 & 27 & 6847.1 & 1 \\
\hline & East & & & & & & & & & & \\
\hline & Popayat & & & 1214. & 0.1 & & & 0.1 & & & 1.7 \\
\hline \multirow[t]{2}{*}{10} & $\begin{array}{l}\text { o } \\
\text { West }\end{array}$ & 7798 & 85 & 6 & 1 & 103 & 647.7 & 6 & 50 & 2881.9 & 7 \\
\hline & Popayat & & & & 0.0 & & & 0.1 & & & 0.8 \\
\hline \multirow[t]{2}{*}{11} & o & 6835 & 99 & 736.6 & 7 & 117 & 413.0 & 0 & 64 & 1447.1 & 9 \\
\hline & & & & 6412. & 0.5 & & 64039 & 15. & & & 0.5 \\
\hline \multirow[t]{2}{*}{12} & Dengilo & 5691 & 25 & 0 & 8 & 7 & .6 & 94 & 60 & 913.9 & 6 \\
\hline & Wangga & & & & 0.0 & & & 0.0 & & & 2.7 \\
\hline 13 & rasi & 4748 & 55 & 707.6 & 6 & 73 & 314.5 & 8 & 20 & 4393.3 & 0 \\
\hline
\end{tabular}

Source: Results of the analysis, 2017. 
Randangan Sub-district has a relatively good accessibility compared to Marisa City and Paguat Sub-districts which are currently in the first and second place in terms of the availability of economic infrastructure. This is because Randangan Sub-district is located in the middle of Pohuwato District, so that the distance between the regions is closer, which also means shorter travel time. Figure 1 below shows the comparison of accessibility from hinterland area to Marisa City, Paguat and Randangan Sub-districts.

Figure 1. Comparison of Accessibility from Hinterland to Marisa City, Paguat and Randangan Sub-districts.

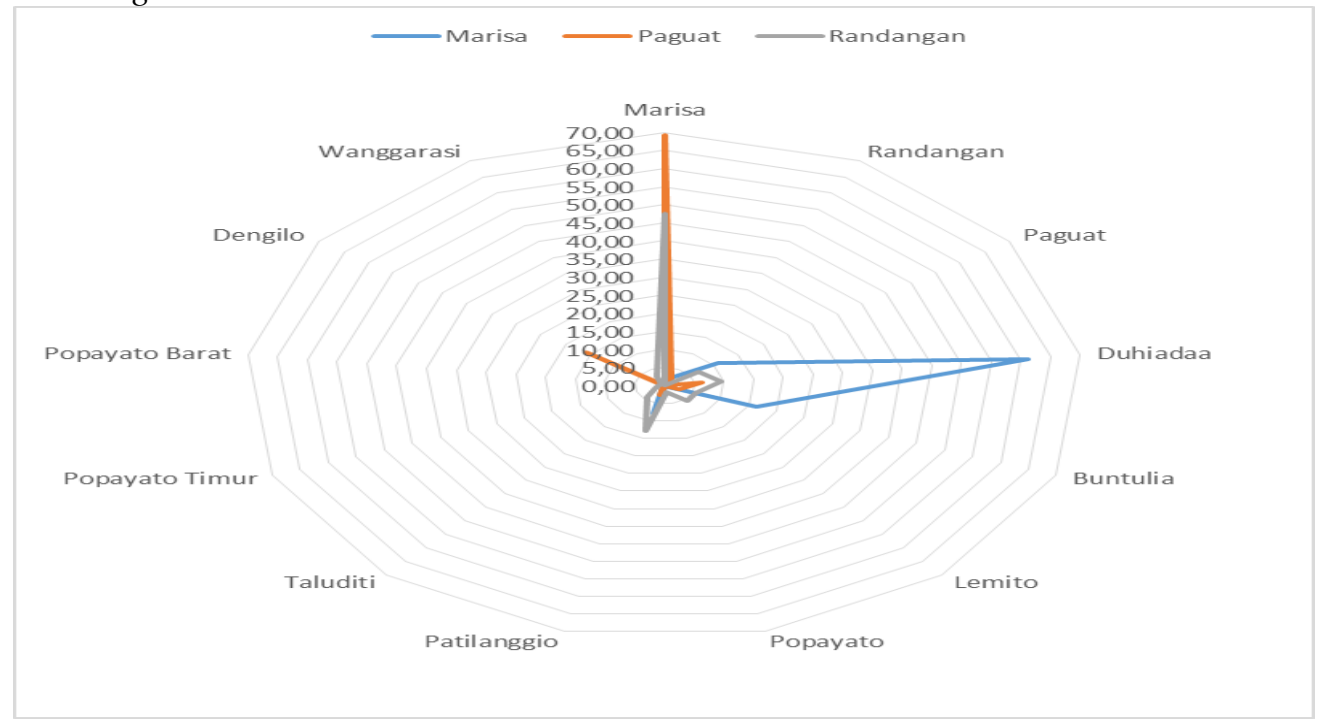

Based on the above graph, there is a gap between the calculated hinterland with a focus on Marisa City, Paguat and Randangan Sub-districts. The attraction results calculated using the gravity model from equation (2), show that Randangan subdistrict has a tendency towards more equitable accessibility in the hinterland areas. It indicates that the accessibility gap between regions with high and low attraction is relatively similar. Conversely, the accessibility gap is present between hinterlands when focusing on Marisa City and Paguat Sub-district. The hinterland region with the lowest and the highest accessibility value, when oriented to Marisa City, are the Duhiadaa (67.16) and West Popayato (0.07) Sub-districts, while the hinterlands that has the highest and the lowest accessibility, when oriented to Paguat Sub-district, are Marisa City (27.78) and Wanggarasi Sub-district (0.03). But if one looks at this from the aspect of the availability of the number and types of economic infrastructure in Randangan Sub-district (588 and 9), this is still below Marisa City (1737 and 10) and Paguat Sub-district (743 and 9). It means that Marisa City already deserves to be the Centre Business District (CBD). To address the accessibility gap, the Municipal Government of Marisa (Marisa Sub-district) is expected to develop a transport infrastructure between the hinterland areas oriented to the Marisa City 
region, so it can establish shorter travel time towards and from the centers of infrastructure service.

\section{Conclusion}

Based on results and discussion, it can be concluded that:

1. The frequency of economic infrastructure activities in providing services in Marisa City towards the hinterland areas is much better than other districts in Pohuwato District. It can be seen from the function index value of Marisa City of 173.70. Marisa City has the amount and type of economic infrastructure service needed, and this completeness of the economic infrastructure is the attraction for residents to carry out their activities in Marisa City. So, it can be said that the capability of the economic infrastructure service of Marisa City is relatively better.

2. Marisa City has poor accessibility due to the its location, which is in the Eastern part of Pohuwato District, meanwhile the hinterland area is located in the western part. It leads to a longer travel distance between the hinterland areas and Marisa City.

3. In general, Marisa City has a good service, as the center of local activities, if it is viewed and measured from the availability and the completeness of the economic infrastructure aspect, so Marisa City can be developed further as the Centre of Business District (CBD) and government service center, to provide services for the citizens and villagers in the hinterland areas in Pohuwato District.

\section{References:}

Abdi, H. 2005. Guttman Scaling. Encyclopedia of Social Measurement, 167-174, https://doi.org/10.1016/B0-12-369398-5/00103-1.

Adisasmita, R. 2010. Regional Revenue and Budget Management. Graha Ilmu: Yogjakarta Adisasmita, R. 2014a. Economic Spatial Regional. Yogyakarta: Graha Ilmu.

Adisasmita, R. 2014b. Growth Regional and Regional Growth. Yogyakarta: Graha Ilmu.

Al Karim, M. 2012. Infrastructure and Regional Economic Growth. Yogyakarta: PWK UGM.

Central Bureau of Statistics. 2016. Pohuwato District in Figure. Pohuwato-GorontaloIndonesia.

Bintarto, R. 1983. Rural-Urban Interactions and the Problems. Jakarta: Ghalia Indonesia.

Haris, A. 2009. Effect of Land Use on the Success of Infrastructure and Economic Development. Jakarta: Direktorat Tata Ruang dan Pertanahan, Bappenas.

Kingsley, H.E. \& Fotheringham, A.S. 1984. Gravity Model Overview: Gravity and Spatial Interactions Models. Sage Published.

Lal, M. \& Pathak, V.K. 2011. Assumptions of Central Place Theory and Gravity Models with Special Reference to Consumer Spatial Behaviour. Journal of Management \& Public Policy, 2(2), 99-108.

Mani Kannan, P. 2015. Mobility Analysis using Gravity Model. École Polytechnique De L’universite François Rabelais De Tours Spécialité Aménagement Et Environnement. 
Marasabessy, F. 2016. Ternate City Hierarchy After Regional Development

Waterfront City. Regional and Environmental Journal, 4(3), 213-224.

McCann, P. 2004. Urban and Regional Economics. New York: Oxford University Press.

Pour, S. \& Firozjaei, A.T. 2012. Investigation the development indicators of Babul's districts based on Scalogram model 1. Journal of Applied Sciences Research, 8(2), 11621167.

Riyadi, \& Bratakusumah, S.D. 2004. Regional Development Planning: A Strategy to Explain the Potential in Achieving Regional Autonomy. Jakarta: Gramedia.

Setiono, N.D. 2011. Regional Development Economics: Theory and Analysis. Jakarta: LPFE UI.

Tuloli, M.Y. 2013. Perspective of Temporal Spatial Development of Gorontalo City. Gadjah Mada University.

Wibowo, R. \& Soetriono, M. 2004. Concepts, Theories and Platforms of Regional Analysis. Malang: Bayumedia Publishing.

Williams, K. 2014. Urban Form and Infrastructure: A Morphological Review, 58. Retrieved https://www.gov.uk/government/uploads/system/uploads/attachment_data/file/3241 61/14-808-urban-form-and-infrastructure-1.pdf. 